\title{
LIVETUR - THE SUBJECT IS TOURISM
}

\author{
Cálidon Costa da Conceicão a; \\ Clêrta Costa da Conceicao b;
}

ABSTRACT: The scope of the project "LiveTur - The subject is Tourism" was to address the academic market, bringing content and professionals with experience and expertise in tourism. In the methodological procedures, a case study was used, with qualitative research of an exploratory and explanatory nature. The results enabled the generation of content that was transformed into an archive of fifty videos on a range of topics, including tourism, hospitality, events and gastronomy, giving an opportunity to share knowledge and experience, as well as to present professionals from various sectors of national and international tourist activity.

\section{KEYWORDS}

Livetur

Social network

Tourism professionals 


\section{INTRODUCTION}

The project "LiveTur - The subject is Tourism" was carried out via the social network Instagram, and was subsequently edited and broadcast on YouTube. The project was started with two aims. The first emerged out of the times in which we are living, with the Covid-19 pandemic, when people are being urged to stay at home as much as possible and therefore have more time to devote to the social networks, providing an ideal scenario for us to present some form of entertainment focused on some of the more technical and scientific issues in tourism.

The second aim was to share knowledge and experiences on a wide range of tourism-related topics, from Community-Based Tourism to the use of technologies in tourism, demonstrating the importance of bringing the market closer to the academic environment, given that many of the solutions that the market is looking for already exist in the academic world, requiring only that the two parties come together.

This lack of coordination between the market and the academic world works both ways: on one hand, the knowledge produced in the academic world tends to remain within its four walls, sometimes forgetting that it needs to be passed on to society in a simpler way, bringing plausible and concrete results through solutions that, however complex, must be passed on so that they can be understood and applied in the market.

On the other hand, the market tends to look only to itself for solutions, without considering that many of these solutions require just a little investment in research, in order to produce the results they are looking for, resulting in the construction of knowledge and know-how that characterizes a coming together of theory and practice. These barriers are slowly being broken down, with companies beginning to invest more in scientific research in search of the solutions they need for their tourism-related activities, particularly in the area of Information Technology and communication (ICT).
The project is justified by the need to share knowledge about tourism activity, through professionals who have demonstrated expertise on the is-

\section{LITERATURE REVIEW}

sues that guide tourism, providing students and teachers with knowledge and sharing experiences, generating new projects and new work partnerships. The study is configured a posteriori, with the presentation of the theme first, followed by the indication of the methodological process used, and the results achieved, which are demonstrated through content, tables and figures that brought personal, social, and intellectual rewards, and particularly, partners who donated their time, knowledge, experience and image in the service of tourism development.

\section{Networks: Contextualization and concepts}

In the contemporary world, the word network has several meanings, from the woven mesh used by fishermen to a complex network of data systems and information. In this sense, the intention is to demonstrate the form of sharing ideas, teaching and learning in social networks focused on tourism.

The term net exists even in mythology, inspiring the imaginations of artisans and what they called a labyrinth. In ancient times, Hippocrates, when dealing with concepts in medicine, saw a clear association with organisms, regarding the way the veins communicate and nourish the flesh (Musso, 2004).

The expression network is initially seen through its etymological origin, which comes from the Latin rete (Souza \& Cardoso, 2011). In some places, a network is seen as a mesh of interwoven strands, such as of nylon, rope, or wire.

Souza \& Cardoso (2011) list a series of possibilities carried by the term network, such as artifacts that can be used to trap animals, or tissues that serve as metallic meshes used for fences. A network can also be seen as a group of persons, organizations or entities that communicate with each other, or it may re- 
fer to a series of transport routes, a communication system, or a computer system.

Musso (2004) asserts that at the beginning of the $19^{\text {th }}$ century, there was a shift in relation to the concept, with networks being observed not only in the human body, such as neural networks, but being constructed through external processes.

The network set up externally now observes how society is organized around the networks. Souza \& Cardoso (2011) present some considerations of the sociologist Georg Simmel who, in his essay The Bridge and the Door, published in 1909, demonstrates that he considers reality in a visible separation from another person, seeking to obtain the possibility of perpetuating and creating a link between the two. He considers this to be the image of aggregation, i.e., the relationship in society itself.

Maffesoli (1998), inspired by Simmel, contributes to the understanding of his method through his metaphor of tribes, classifying it as a network of networks and indicating that these networks are comprised of people. He goes on to consider tribes in multiple ways, where there is the involvement of one with the others. Nevertheless, each tribe has its followers, who relate with one another through signs that converge towards common interests, and possibilities for understanding their needs and attitudes.

The expression "tribe" contributes to the understanding of networks in the sense of the social involvement of individuals that are correlated, because the interconnections between these individuals, within a certain group that relates, are intersections that comprise a network.

Dias (2005) describes a network as a human invention like so many others; he considers only a social construction, in which groups or individuals, as well as institutions and companies, can carry out social, political or economic actions.

Castells (2000) states that networks are open structures capable of disseminating new nodes, provided that they can communicate and share the same communication codes in a limited way.

Information sharing is the basic foundation of networks, because it is through them that the communication process is exercised, so that there is interaction between their peers in order to obtain results that will benefit all their stakeholders (Conception, 2018). Minasi \& Silveira (2016), consider that it is necessary for the actors of a network to identify common points of interest and actions that can be carried out, bearing in mind that these objectives and actions should bring benefits for all the participants. The common point of the network proposed here is focused on tourism activities.

Trumblay (1998), demonstrates the significance of networks for tourism, stating that it is important to have integration among the various service providers of tourist destinations, as well as for the formation of strategies that will enable strategic alliances between entities and companies that may be connected in relation to services, points of promotion and direct sales in the sending markets of tourist regions.

The existing networks are diverse, and in the case of this project, the involvement is not only linked to the activities of sharing information but to content directed to a specific activity, in this case tourism. The support network used for this event was social networks, as will be seen later. Social Networks prioritize people, groups, and institutions that seek to organize themselves and obtain common information and objectives (Schlithler, 2010).

Minasi \& Silveira (2016) comment that social networks can be configured based on the involvement and interest between two or more social actors with the desire to establish some kind of relationship. Souza and Cardoso (2011) commented on the network in 1909 and Maffesoli, (1998), through his considerations about sociability in groups and networks, considers the use of the social network today, as a structure composed of organizations and people that connect with different types of relationships, common objectives and values, suggesting the movement and flow of people to meet standards, considered relationships that incorporate the concepts used by a society.

\section{Social network on the Internet}

The term Social Network was first described by the researcher J. A Barnes in 1953, in a short document 
intended to communicate (pass information on a specific subject), which was officially published in 1954. And the expression has been used ever since (Souza, Freitas \& Biagi, 2017).

The Social Network was initially used to describe and give visibility to notions of class equality in the city of Bremmes, Norway. Barnes was inspired by the ideas of Radcliffe-Brown (1940) who demonstrated, in his writings, references on the social structure as a network of relationships (Barnes, 1972).

Introducing his concept of social networks, Barnes understood that a network would enable all or just a part of society to be immersed together, creating entanglements and interrelationships that were perceived through the diversity of individual or group relationships (Souza, Freitas \& Biagi, 2017).

There are several concepts related to the theme of social networks, but the issues that highlight these definitions involve individuals or groups that establish connections by various common prisms and affinities that they have in common, thus tracing lines of involvement and interrelations between two or more people.

Social networks can be considered an immaterial concept, as their involvement occurs through social interactions and relationships among the most diverse actors, these relationships being built on knowledge, values, information, efforts and interests that demonstrate the same objectives (Degenne \& Forse, 1999).

Matos (2011) refers to Social Network as a group of persons or groups with common interests and motivations that come together for a certain period of time, whether long or short. The Social Network may be dispersed or closely joined. In the case of the use of Social Networks, Recuero (2009) corroborates this, affirming that it allows individuals to connect in cyberspace, enabling social exchanges and interactions that may be reactive or mutual.

Social networks on the Internet include representations of the various different actors and their social connections (Motta \& Perinotto, 2012). Online Social Networks can be considered one of the main discoveries or findings of technology of the contemporary world, contributing exponentially to the development of the travel and tourism sector (Souza, Freitas \& Biagi, 2017). Social Networks have both negative and positive aspects. The negative aspects include excess information that lacks real data and foundation, i.e., spreading fake news. Positive aspects are that they can reach a significant number of people and groups, and their capacity to disseminate content (Souza, Freitas \& Biagi, 2017). Perinotto (2013) believes that social networks will continue to grow, both in terms of the numbers of users and their interactions. He comments that certain national and international studies have identified and recognized Social Networks as a platform for travel planning and research, capable of influencing consumers in their decision-making.

When it comes to online sharing, Belk (2013) ensures that technology tools are essential to transmit information about oneself, online. That is why I believe it is necessary to use this means of communication as a tool for the transmission of live videos, because they are significant and important for informing participants about the most diverse contents aimed at groups, people or institutions of a specific segment.

Souza, Freitas \& Biagi (2017) argue that the use of the Internet through sharing sites, such as social networks, blogs, and flogs, among others, gives users its most diverse uses, such as the creation of personal content focused on family and friends, through videos, photos and music, having social networks as allies in the dissemination of knowledge, whether in an entertainment, technical or scientific format.

Social media are very diverse, and Instagram can be highlighted as a strong tool for sharing content through mobile devices. Instagram was therefore chosen as the social network to be used to execute the project LiveTur - The subject is tourism, due to its ease of use and the opportunity to disseminate and reach people or groups through tourism activities. Through social networks, the ideas and actions of a particular sector can be legitimized and strengthened (Minasi and Silveira, 2016).

The Social Network Instagram was launched free of charge, in 2010, and was initially based on photo sharing. It allows its registered users to post photos immediately, in a natural way or through the use of filters, and share them instantly on their profiles. (Moretti, Bertoli \& Zucco, 2016).

Digital information is increasingly accessible to the public, as well as new tools, websites and social networks that have appeared and gained in popularity, 
using them as a vehicle for the dissemination of content and tourist destinations (Cruz, Motta \& Perinotto, 2012).

The Instagram Social Network was chosen because it was believed to be the means of divulgation that could reach the largest number of people interested in seeing professionals and contents on a wide range of tourism scenarios. Thus, the aim of the Live videos was to interact with the people or groups seeking to share knowledge about tourism.

\section{METHODOLOGICAL ASPECTS}

The methodology used was qualitative research, with exploratory and explanatory approaches. This contributed to the construction of the project and the presen- tation of its phases, from its conception until the moment through to the report of the results.

Thiollent (2000, p. 25) defines a methodology as a mode of general knowledge comprised of the skills necessary for researchers, with the purpose of guiding them in the research process and decision making, in terms of the selection, concepts, hypotheses, data and techniques appropriate to the research to be carried out.

When dealing with methodology, some aspects will be presented that corroborate this understanding, as well as the process and elements that are part of the construction of the project Livetur - The subject is tourism, including the understanding that the methodology uses specific knowledge of certain content. Thinking through this prism, Luckesi (1985) states that knowledge should be characterized as a mechanism

Figure 01 - Stage 1 - Pre-Live

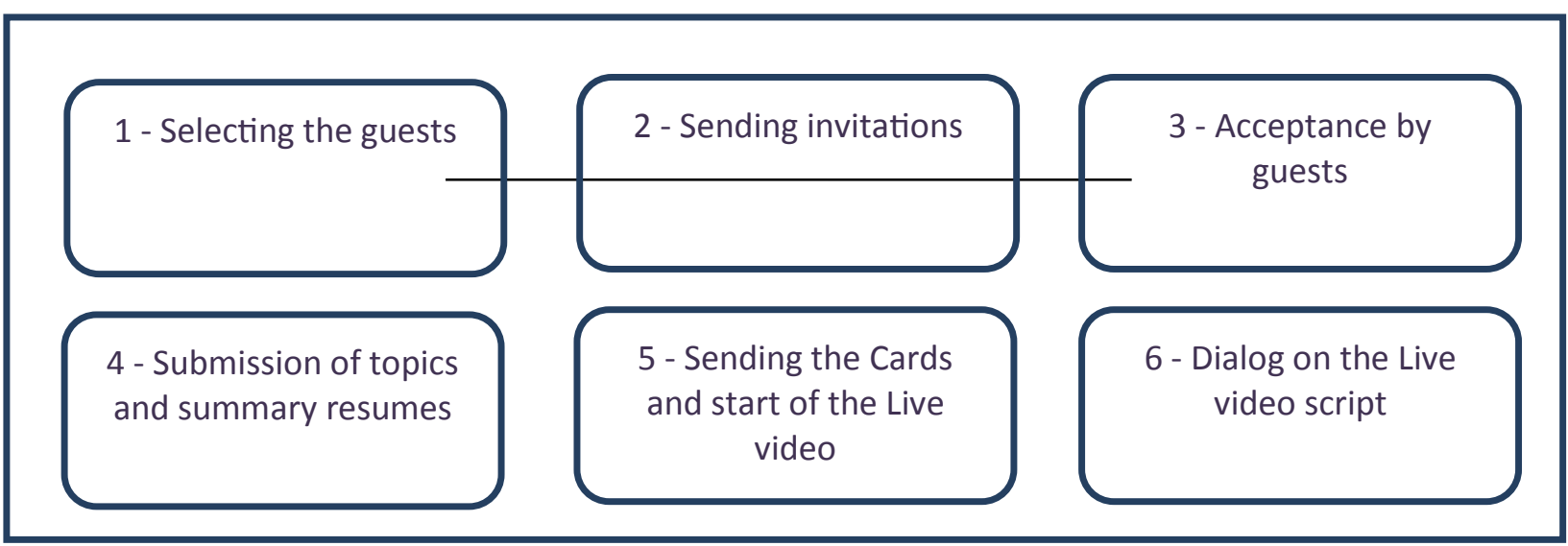

Source: Prepared by the author (2020)

\section{- Selecting the guests}

The guests were selected in two ways: first, based on the professional's knowledge of the theme, with proven scientific research and market recognition. Second, based on how the guests were able to convey that knowledge and experience during the Live videos, as they already had experience of teaching in classrooms or successful careers, adapting only the way content is presented for the online format.

\section{- Sending invitations}

project and its structure were explained, along with all the steps and procedures that would take place for the project to be carried out successfully, up to the time of the Live video.

\section{- Acceptance by guests}

The guests then accepted, and were asked to provide some information so that the Live video could take place without any problems, and to give the guests the opportunity to make their best possible contribution. 
that transforms and understands the world, with the ability to perform the action that can represent a means of contributing to knowledge sharing.

The related to the procedures pointed out in this research can be characterized by the use of techniques that enable the proposed objective to be achieved. Thus, the method described a posteriori refers to the understanding of Michel (2009, p. 50), affirming that the method can be understood as an "orderly device or a set of systematic procedures used to obtain a desired result".

For this research, the case study was used, because its purpose is to represent the phenomenon studied so that it presents the meaning in a form that is representative of a given study. There is a similarity with the field research in relation to its data collection and anal- ysis, such as the care to be assertive in order to present questions and reliable elements of information collected, analyzed and presented (Conception \& Conception, 2016).

Yin (2001) affirms that the researcher, when choosing his case, must be representative and significant, to present his reasoning and generalization, thus creating opportunities to point out positive inferences about the theme. The data collection must be rigorous and recorded with due rigor, following all the procedures of the field research.

The interviewees' information was based on personal information and technical content obtained through the use of their verbal information, through emails, social network and passed on by WhatsApp, and their data were confirmed through their curriculum vitae, available on Lattes platform of the National Council for Scientific and Technological Development (CNPq).

Figure 02 - Phase 2 - Live

\section{- Proposed theme}

- Professional background

- Divulgation of the Content
Involvement of the participants of the Live video

- Voluntary participation of those present

- Comments

- Questions
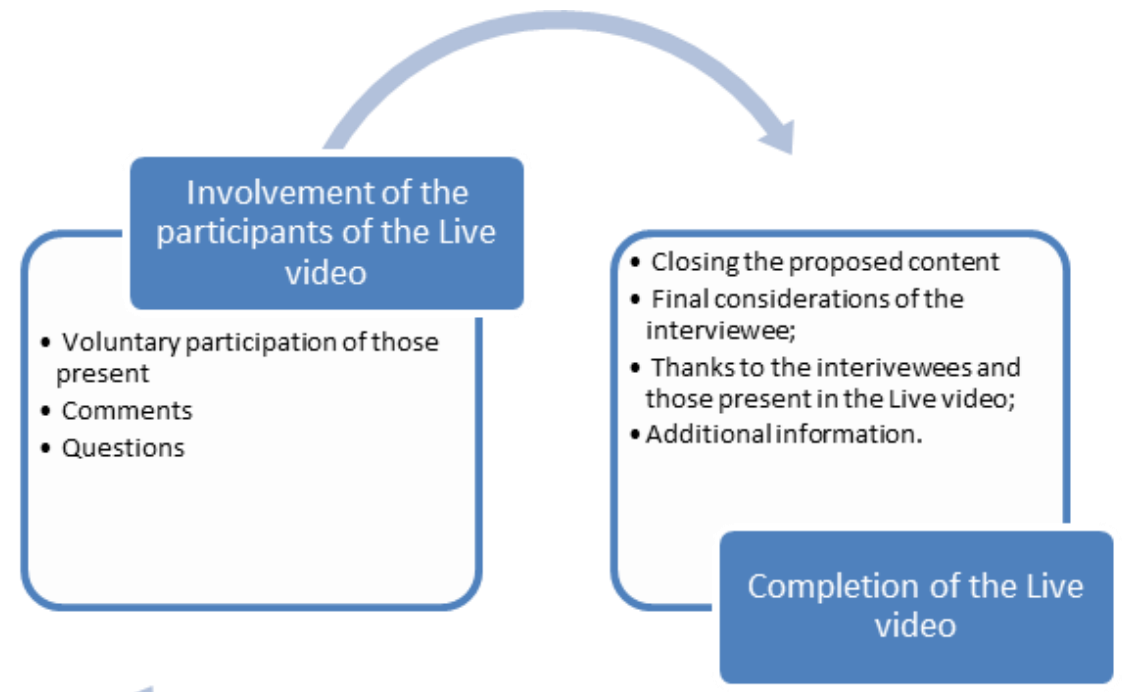

Presentation of the theme and professional background

Source: Prepared by the author (2020) 


\section{Building blocks of the Project}

The project LiveTur - The subject is tourism was held between April 22 and July 27, 2020, on the social network Instagram @calidon, always at 18:00 p.m. Brasília time. The first 5 weeks were held from Monday to Friday (5 live videos per week); on the following 3 weeks they were from Monday to Thursday (4 live videos per week), then in the 3 weeks thereafter, from Monday to Wednesday (3 live videos per week), and in the final 3 weeks, on Monday and Tuesday only. (2 live videos per week). Later on, the Live video was edited and retransmitted via YouTube on the channel Cálidon Costa - The Subject is Tourism. A total of 50 individuals were in- cluded.

The Project LiveTur - The subject is tourism, consisted of 3 distinct stages: 1 - Pre-Live; 2 - Live E; 3 - post-Live. These phases will be presented in detail, showing what took place in each one.

\section{Stage 1 - Pre-Live}

Pre-live is the stage of design and preparation of the project. In this stage, there were several important implications for carrying out the project. We wanted to have guests that would bring experiences and knowledge about tourism from various different perspectives. Therefore, on the understanding what we wanted to present the videos to all professionals, students and teachers in the areas of tourism, hospitality,

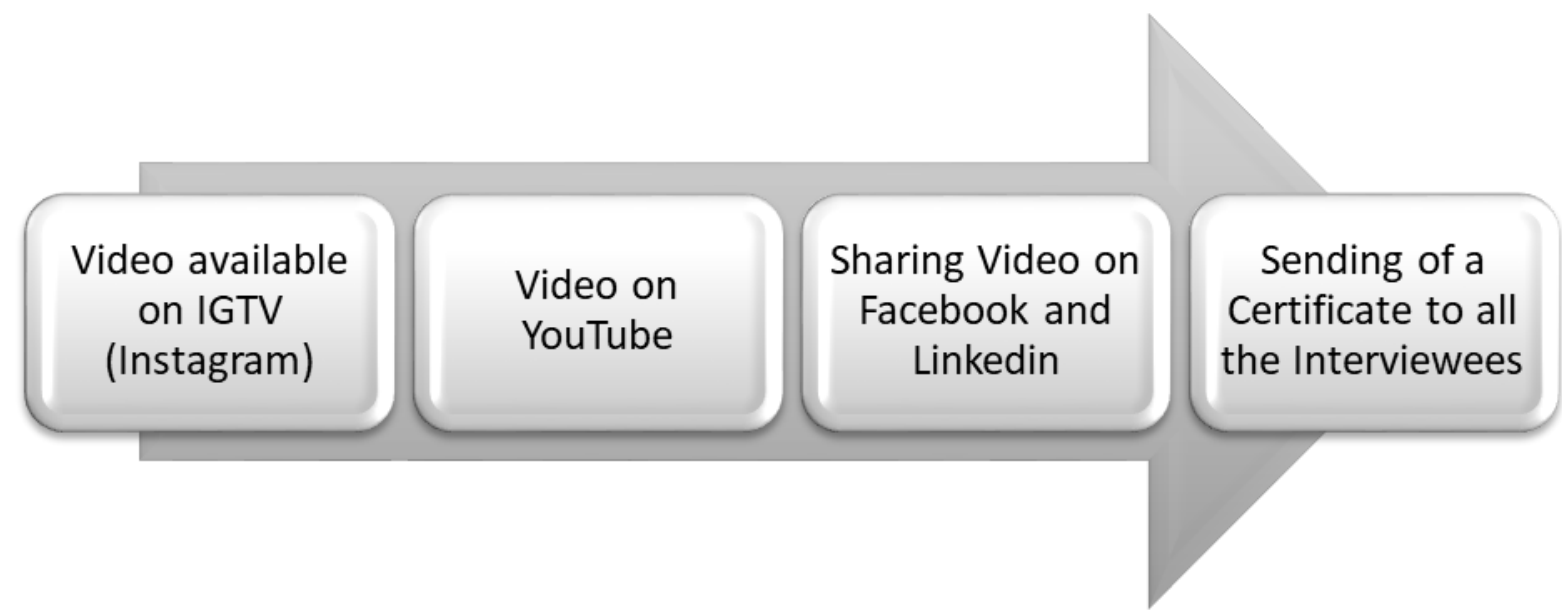

Source: Prepared by the author (2020)

\section{- Video available on IGTV}

After the Live video had ended, it was immediately made available by Instagram's IGTV, giving those who were unable to watch it live the opportunity to watch the full video.

\section{- Video available on YouTube}

The Live video was subsequently edited and made available on YouTube, as previously mentioned. Remembering that this edition was only to put the char-

\section{- $\quad$ Sharing videos on Facebook and Linkedin}

A days after the video was shown on YouTube, it was also shared on Facebook and Linkedin, in order to reach as many people as possible, publicizing the professionals and the topics that are so important and significant for tourism.

\section{- Sending acknowledgments and certificates to all the interviewees.}

At the end of all the Live videos, the interviewees were informally thanked for their willingness and generosity in being part of this project (Appendix D). 
gastronomy and events, the next stage was to build all the phases. Phase 1 is represented by figure 01 .

\section{- Submission of topics summary resumes}

Once the guests had agreed, they sent in their chosen topic (Appendix A) and a summary resume, bearing in mind that the fact that they had been invited meant that we already had as references some research proposals and knowledge of the guest's professional performance. So we did not impose the topics, since the purpose was to present content from the most diverse areas during the week of the Live video.

\section{- Sending the Cards and start of the Live videos}

On receiving the resume and information on the proposed theme, we prepared the cards (Appendix B) and sent them to the guests for their opinions and confirmation of the information contained in them. Once approved, the cards were divulged on the social networks Instagram, Linkedin, and Facebook.

\section{- Dialog on the Live video script}

On the day of the Live video, a dialog was established between the interviewee and the interviewer so that they could address the content that would be talked about in the video, as well as technical questions. It should be emphasized that this dialog was only to find out what route the interviewees wanted to follow, leaving them as free as possible to express their thoughts and opinions, and giving them complete freedom to present the proposed content.

\section{Stage 2 - Live videos}

The Live video was the main moment of the project, in which the interviewees and viewers were able give their opinions and ask questions live, seeking to contribute in some way to the content of the day and sharing and exchanging knowledge about their tourism activities.

The Live videos generally followed an order that was as clear as possible, and all those present were encouraged to participate. The videos started by presenting the theme and the professional background of the interviewee. This was followed by the participant involvement, and the completion, as shown in Figure 02.

\section{- Presentation of the theme and Professional background}

First, the subject and professional background of the interviewee were presented. We believe it is interesting to present this background because these professionals have had experiences, and even struggles, in order to become successful in their careers, and this could be an inspiration to others.

\section{- Involvement of participants in the Live video}

The project has always intended to contribute to the tourism sector in a professional and technical way, building content that can involve and reach people interested in learning more about this activity. The Live videos, therefore, aimed to provide the greatest possible interaction of the participants, through comments and questions.

\section{- $\quad$ Completion of the Live video}

The completion of the live video was seen as a time not to say goodbye, but for encounter, giving the participants a chance to interact and form future professional and academic partnerships.

At the end, there was an opportunity to thank all the interviewees and participants for their willingness to join us during those sixty minutes, and some information was given about what had taken place and what would take place in the upcoming events.

\section{Stage 3 - Post-Live}

The post-live phase was critical for sharing content and videos on other online platforms. In this phase, besides sharing the video on Instagram (IGTV), Facebook and Linkedin social media, it was also made available on YouTube on the channel Callidon Costa - the subject is Tourism. In addition to these shares, acknowledgments and certificates were sent to all the interviewees. Figure 03 represents Phase 3, as shown below.

A certificate was also sent (Appendix C) showing the interviewee's name, the topic of their video, date, and Live link.

\section{RESULTS ACHIEVED}


This project sought to contribute during this difficult time that we are all going through, bringing knowledge and experiences about the tourism sector through the most diverse perspectives, with the aim of enabling professionals, teachers and students to interact with Doctors, Masters and Specialists who work directly with tourism.

The results achieved included professional and personal aspects, with regard to the involvement of so many partners who contributed to the existence of this project, especially the interviewees, as the protagonists, bringing relevant, pertinent and current contents about the tourism activity.

The results can be listed as follows; first was the legacy that we wanted to leave from the project, and I believe that what we call the largest "catalog of professionals and tourism themes in Brazil" was achieved and made available on Instagram and YouTube.

The second was the use of these Live videos in classrooms of universities all over Brazil, as well as in public and private institutions seeking to gain a better understanding of specific topics.

The third occurred through the possibility of leaving a legacy involving the sharing of knowledge and experiences, inspiring professionals and especially students, who are sometimes somewhat discouraged with the profession. Nevertheless, it was encouraging to be able to interview fifty highly qualified professionals, demonstrating how rich our country is in brains that develop and promote tourism activities of Brazil.

\section{FINAL CONSIDERATIONS}

This report was characterized by the search to contribute to the dissemination of knowledge in relation to tourist activity in its most diverse segments, with the aim of bringing together the market and academia, providing professionals, teachers and students with an archive of more than fifty videos, featuring interviewees who, besides their knowledge, also have a wealth of experiences in tourism, including doctors, teachers and specialists from various academic and market areas.

This project emerged mainly out of the times in which we are living, which is the Covid-19 pandemic. It has forced us, and at the same time gave us the opportuni- ty, to look differently at the innovations and technologies used as tools that contribute to the dissemination of knowledge.

Thinking about technologies, and how to maximize the use of social platforms and networks for sharing all forms of content, the idea arose to build a project that would highlight the professional and academic qualifications of the tourism sector. In this sense, I believe that this project has made a significant contribution to tourism in its most diverse segments.

\section{REFERENCES}

Anana, E., Anjos, F., Pereira, M. (2016) Imagem de destinos turísticos: avaliação à luz da teoria da experiência na economia baseada em serviços. Revista Brasileira de Pesquisa em Turismo. v.10, 309-329.

Barnes, J. A. (1972). Social Networks. Cambridge: Module

Belk, R. W. (2013). Possessions and the Extended Self. Journal of Consumer Research, 15, 139-168.

Conceição, Cálidon C., Conceição, Clêrta C. (2016). Metodologia do Trabalho Científico: normas, técnicas e procedimentos. Porto Alegre: Luminaria Academia.

Castells, M. (1999). A sociedade em rede - A era da informação: economia, sociedade e cultua. São Paulo: Paz e Terra.

Cruz, V. L., Mota, K. M., \& Perinotto, A. R. C. (2012). Redes Sociais da Internet: Estratégia para Divulgação das Potencialidades Turísticas do Piauí/Brasil. Rosa dos Ventos-Turismo e Hospitalidade, 4, (1)

Dias, L. C. (2005). Os sentidos da rede: notas para discussão. In: Dias, L., \& SILVEIRA, R. (Org.). Redes, sociedades e territórios. Santa Cruz do Sul: Edunisc.

Ferrari, C. M. M., \& Gandara, J. M. (2015). Fotografias de viagens: replicando cenas da viagem perfeita em Curitiba/PR. Caderno Virtual de Turismo. Rio de Janeiro, 15 (2), 112-130.

Fratucci, A. C. Refletindo Sobre a Gestão dos Espaços Turísticos: perspectivas para as redes regionais de turismo. Turismo em Análise, 20 (3), 391-408.

Flecha, A. C., Silva, A. V. C., Fusco, J. P. A., \& Bernardes, A. T. (2012). Redes de empresas e seus efeitos sobre o turismo. RAE, São Paulo, 52 (4), 386-406.

Knupp, M. E. C. G., \& Mafra, F. L. N. (2012). Redes do Turismo: uma análise da política de turismo do Estado de Minas Gerais Brasil. Turismo em análise, 23 (3), 663- 690.

Marteleto. R. M., \& Silva, A. B. de O. (2004) Redes e capital social: o enfoque da informação para o desenvolvimento local. Ci. Inf, Brasília, 33 (3), 41-49. 
Marteleto, R. M. (2001). Análise de redes sociais - aplicação nos estudos de transferência da informação. Ci. Inf, Brasília, 30 (1).

Matos, R. (2011). Territórios e redes: dimensões econômicomateriais e redes sociais especiais. In: Dias, L. C., \% Ferraril, M. (orgs.). Territorialidades humanas e redes sociais. Florianópolis: Insular, 167-188.

Maffesoli, M. (1998). O tempo das tribos: o declínio do individualismo na sociedade de massa. Rio de Janeiro: Forense Universitária.

Musso, Pierre. (2004). A Filosofia da Rede. In Parente, A. (org). Tramas da Rede: novas dimensões filosóficas, estéticas e políticas da comunicação. Editora Sulina.

Michel, M. H. (2009). Metodologia e pesquisa científica em ciências sociais. São Paulo: Atlas.

Moretti, S. L., Bertoli, B. J., \& Zucco, F. D. (2016). A imagem de Blumenau no Instagram: um estudo sobre destino turístico em redes sociais usando equações estruturais. Caderno Virtual de Turismo, 16 (1)

Perinotto, A. R. C. (2013). Investigando a comunicação turística de Parnaíba/PI-Brasil: Internet e redes sociais, descrição e análise. Málaga/Espanha. TURyDES-Revista de investigación en turismo y desarollo local, 6 (15).

Recuero, R. (2009). Redes Sociais na Internet. Porto Alegre: Sulina.

Minasi, S. M., \& Silveira, R. L. L. (2016). Redes sociais e turismo: reflexões no contexto do desenvolvimento regional, Turismo e Sociedade, Curitiba, 9 (2), 1-19.

Santa'Anna, A. L. P., \& Jardim, G. S. (2007). Turismo on-line: oportunidades e desafios em um novo cenário profissional. Observatório de Inovação e Turismo - Revista Acadêmica. [s.I.], 2 (3), 1-14.

Santos, M. (2002). Território e Dinheiro. In: Território e Territórios. Niterói: Programa de Pós Graduação em Geografia PPGEO-UFF/AGB.

Schrerer-Warren, I. (2007). Redes Sociais: Trajetórias e Fronteiras In: Dias, L.C., \& Silveira, R. L. L. (Org.) Redes, sociedades e territórios, EDUNISC, 29- 50.

Schneider, H. N. (2006). Educação a distância via internet (elearning): Contextualização (Know What), Justificativa (Know Why), Implantação (Know How). Aracaju: Rev. Candeeiro, 13-14, 40-47.

Schlthler, C. R. B. (2010). Redes Intersetoriais de Desenvolvimento Comunitário. [s.I.].

Souza, G., Freitas, T. G., \& Biagi, C. R. (2017). A relação das mídias sociais na construção da autoimagem na contemporaneidade. Akrópolis, Umuarama, 25 (2), $117-$ 128.

Souza, M. S., \& Cardoso, C. (2011) As Redes Sociais Digitais: Um mundo em transformação. Agenda Social, 5 (1), 65 - 78.
Cortez.

Yin, R. K. (2010). Estudo de caso: planejamento e métodos. Porto Alegre: Bookman.

Xiang, Z., \& Gretzel, U. (2010). Role of social media in online travel information search. Tourism Management, 31 (2), 179-188. 